\title{
QUALITY STANDARD IN EDUCATION \\ OF INDIVIDUALS WITH VISUAL IMPAIRMENT
}

\author{
Dita Finková
}

\begin{abstract}
In recent years, the importance of education has kept on growing, and therewith also demands for quality of education. It is not only the demands of healthy population that are important, but also demands for the quality of educational process for persons with disabilities, specifically persons with visual impairment. The text is focused on the issue of utilizing "incentive measures" in educational process of pupils with visual impairment. Such incentive measures are considered to be the use of special methods, approaches, forms and means of education, furthermore utilizing assistive and physiotherapeutic equipment, special textbooks and teaching materials, inclusion of subjects from special educational care (e.g. spatial orientation, teaching PC work, speech and language therapy), reduced number of pupils in a class, provision of an assistant teacher as well as other measures. Implementing "incentive measures" directly impacts quality of education provided to these persons. Actual utilization and expedience of "incentive measures" was surveyed in the Czech Republic's territory at schools for persons with visual impairment. Analysis of the current state and its evaluation, with the option of providing feedback to respective facilities and utilizing the processed information, seemed to be a suitable option. Research was carried out with the assistance of pupils with visual impairment as well as with teachers participating in education.
\end{abstract}

\section{Keywords}

Quality of education, standards of education, visual impairment, support measures.

\section{GROUNDWORK DATA ON THE ISSUE}

Within the last few decades, the right of people with health impairment to education is an indicator of the level of advancement of a given country. From the general point of view, it is possible to say that every individual is unique, whether we are talking about an individual without impairment or with a handicap. This uniqueness is reflected in one's particular needs. After considering all the circumstances relating to the scale of possible impairments (either visual 
impairment or multiple handicap), it is necessary to select the optimal possibilities for education and the correct approach extended to visually impaired people, both imparted with utmost care. From the point of view of the necessity of individual approach, the issue of education of pupils and students with visual impairment is very demanding.

At present, there exists no precise statistics on the number of people with visual impairment in the Czech Republic or elsewhere in the world. A British organisation (RNIB - Royal National Institute of Blind) has recently mentioned a certain ratio of people with visual impairment in a given society and puts this ratio somewhere between $1.5-2 \%$ of the population of a given country. For the Czech Republic, this percentage accounts for up to 150,000 people with some type of visual handicap. We are, however, not able to ascertain with more precision how many of them rank as pupils and students.

Focussing on the field of medicine, we ascertained that, nowadays, physicians are, in the majority of instances, able to save prematurely born babies. These are babies who, as consequence of their premature birth for whatever reasons, weigh only a few hundred grams. There is possible increased risk of occurrence of visual impairment in prematurely born babies. Babies most at risk are those with delivery weight below $1,500 \mathrm{~g}$ and born between $22-25$ weeks of gestation. A high-risk factor in the developed world is, in the first place, the rising age of women in labour, higher number of multiple pregnancies and artificially assisted reproduction.

The demanding nature of looking after such a child is much higher than taking care of an intact child. Additionally, the future options for the child's development and his/her work experience, in relation to the education possibilities, are considerably limited. It is, however, necessary to state one more fact. As stated above, even the present-day prime quality medical care with outstanding diagnostics facilities is unable, in the prenatal stage of a child's development, to uncover pertinent and impending visual impairment which consequently influences the entire life of such an individual. In addition, some types of visual impairment are not evident immediately after birth but the disorder demonstrates itself only in the following developmental stages. An example of such a disorder is the ROP syndrome. From the statistics of new-born babies of the Czech Statistical Institute (ČSÚ) and the National Register of New-born Babies kept at the Institute of Health-care Information and Statistics of the Czech Republic (ÚZIS ČR) follow the below-stated data. CHODOUNSKÁ (2010, p. 2) states as follows: "In 2010, $7.7 \%$ of lively born babies were delivered with low birth weight (below 2,500 g). Higher ratio of children with low birth weight is always noted in girls $(8.5 \%)$ than in boys $(6.9 \%)$."

The issue of education and, especially, the equal right to education is anchored in Act No. 561/2004 of Coll. of pre-school, primary, secondary and higher professional and other education, as amended by later regulations. Another springboard in this respect is a public notice No. 73/2005 Coll. of education of child- 
ren, pupils and students with specific education needs and children, and the pupils and students with extraordinary talent, as amended by later regulations. The above-mentioned documents claim that education of pupils with special education needs (this category including, among others, also the learners with visual and combined impairment where one of the impairments is visual) is provided by means of "subsidiary measures", which differ from or are provided beyond the standard individual pedagogical and organizational measures related to educating learners of the same age in schools, which are not specially established for pupils with health impairment. Under "subsidiary measures" we understand education applying special methods, processes, forms and means, using compensatory rehabilitation and education tools, specially conceived textbooks and didactic materials incorporating the subjects of special-need pedagogical care, the provision of pedagogical and psychological services, the appointing of a teacher assistant, reducing the number of students in a class etc. The abovestated public notice states clearly that a pupil with health impairment is to be, in preference, educated in manner facilitating individual integration into a standard school if it corresponds with his/her needs and abilities, and if it complies with the conditions and possibilities of the given school. This declares obvious preference of integrated education to educating a student in a "special" school. All mentioned factors can also have a significant impact on the quality of education for these pupils and students.

The individual facts mentioned within our text form the basis for selecting the theme of the on-going project PdF_2012_009 called "Education of Individuals with Visual Impairment in the Context of Education Quality" within the Student's grant competition announced by the Palacký University Olomouc. On the general level, the objective of the project is to analyse the current demands on the standards of education quality of people with visual impairment in reference to the legislation of the Czech Republic.

The issue of implementation of subsidiary measures plays a crucial role in the process of education and development, having direct impact on the quality of education of individuals with visual impairment. Real application and usefulness of such measures, as well as the possible complications in the course of their application in the teaching process, have not been examined in any way from the practical point of view so far. An ideal solution in this situation would be an analysis of the existing status with subsequent evaluation, including the provision of feedback to responsible institutions that might put the ascertained information in practice. The key issue here is then to carry out an analysis of the current status in the field of quality of education of pupils and students with visual impairment within the standard "stream" of education as well as within the special-need education in the Czech Republic, using subsidiary measures and focusing on their importance within the process. The integrated type of education of pupils and students with visual impairment would not be thinkable without these measures. Their general purpose is mentioned in Act No. 561/2004 of 
Coll. And in a public notice No. 73/2005 of Coll., as amended subsequently. Their practical applicability, helpfulness as well as the possible complications in practice, has, however, not undergone any survey as yet.

Within the project, we also focus our interest on the relation between the quality of education and the consequent views, as well as real implementation of further education with respect to the issue of preparing learners with visual impairment for future professions. It is important to take into account the competencies of graduates that correspond with the allotted contents in the Frame Educational Programme for Primary Schools.

Last but not the least, we also need to pay our attention to the prevention and awareness of the target group with respect to the issue of quality of education, directed both at the students with visual impairment and the respective teachers, school consultants and other personnel involved.

As no comprehensive research of such form has yet been conducted and in the extent focussing on the subsidiary measures within the integrated education in the Czech Republic, our project should, therefore, bring new information and experience, which might be applied when enhancing training programmes for future teachers and special-need teachers or it can serve as an information source for innovations in teaching the learners with specific needs, e.g. in the creation of individual learning plans, in devising school curricular programmes in particular schools, etc.

The principal subjects of the research are individuals with visual impairment attending special schools for visually impaired students as well as pupils from the integrated education. Teachers working with visually impaired students and teaching assistants are also subjected to the research.

\section{METHODOLOGY}

From the methodological point of view, our project is, above all, regarded as quantitative research. The principal methods for this research are a dialogue and a questionnaire. Quantitative methodological approach is considered as a form of data gathering, either through a controlled dialogue or a questionnaire, and their evaluation by the defined criteria. Quantitative research is a method of standardized scientific research describing perceptions by means of variables (signs), which are construed to measure certain allotted features or ratio levels. Subsequent results are processed and interpreted by the help of methods designed for statistical research data processing. One of the most convenient methods of data collection, the most demanding at the same time, is controlled dialogue. In the event of this research, our dialogue is monitored and carried out with a certain objective and purpose. We decided for a semi-controlled interview, which is, most likely, the most frequently applied form of interview as it manages to overcome many disadvantages of a fully uncontrolled as well as strictly con- 
trolled interview. The questionnaire method is more convenient in the event of gathering data from a higher number of respondents and represents a research tool for inquiring information on the views of a concrete fact, on value preferences and personal knowledge. A questionnaire is advantageous due to its relative easiness and prompt administration and quantifiable results. In the event of this research, we opt for a semi-standardized questionnaire.

\section{RESEARCH RESULTS}

In this section, we present the partial results of the questionnaire investigation, which was carried out in two primary schools for visually impaired pupils (Brno and Litovel) and focused on subsidiary measures. This investigation may be regarded as a pre-research to be followed with further investigations in other primary schools for the visually impaired and also in pupils with visual impairment integrated within the standard education system.

Tab. 1: No. of pupils participating in the conducted investigation

\begin{tabular}{||c|c|c|}
\hline \multirow{2}{*}{ No. of pupils investigated } & Brno & Litovel \\
\cline { 2 - 3 } & 22 & 31 \\
\hline
\end{tabular}

Altogether 53 pupils underwent the research investigation, out of which 31 were from the Primary School for the Visually Impaired in Litovel and $22 \mathrm{pu}-$ pils from the Primary School for the Visually Impaired in Brno.

Tab. 2: Gender classification of pupils

\begin{tabular}{||l|l|l|l|l||}
\hline \multirow{3}{*}{ No. of pupils investigated } & \multicolumn{3}{|l|}{ Brno } & \multicolumn{2}{l||}{ Litovel } \\
\cline { 2 - 5 } & girls & boys & girls & boys \\
\cline { 2 - 5 } & 13 & 9 & 16 & 15 \\
\hline
\end{tabular}

Altogether 24 boys underwent the research investigation, out of which 9 were from the primary school in Brno and 15 boys from the primary school in Litovel. As for girls, altogether 29 girls were investigated, out of which 13 girls were from Brno and 16 girls from Litovel. 
Tab. 3: Classification of pupils by school years

\begin{tabular}{||l|l|l|l|l||}
\hline \hline School year & \multicolumn{2}{l|}{ Brno } & \multicolumn{2}{l|}{ Litovel } \\
\hline & girls & boys & girls & boys \\
\hline $1^{\text {st }}$ year & - & - & 1 & 4 \\
\hline $2^{\text {nd }}$ year & - & - & 2 & 1 \\
\hline $3^{\text {rd }}$ year & - & - & 2 & 2 \\
\hline $4^{\text {th }}$ year & - & - & 3 & 1 \\
\hline $5^{\text {th }}$ year & - & - & 2 & 2 \\
\hline $6^{\text {th }}$ year & 6 & 2 & 1 & 1 \\
\hline $7^{\text {th }}$ year & 1 & 5 & 1 & 2 \\
\hline $8^{\text {th }}$ year & 2 & 1 & 4 & 1 \\
\hline $9^{\text {th }}$ year & 4 & 1 & - & 1 \\
\hline
\end{tabular}

Out of the total number of 53 participants, 5 pupils attended the $1^{\text {st }}$ year, 3 pupils attended the $2^{\text {nd }}$ year, 4 pupils were from the $3^{\text {rd }}$ year, 4 pupils from the $4^{\text {th }}$ year, 4 pupils from the $5^{\text {th }}$ year, 10 pupils from the $6^{\text {th }}$ year, 9 pupils from the $7^{\text {th }}$ year, 8 pupils from the $8^{\text {th }}$ year and 6 pupils from the $9^{\text {th }}$ year.

Tab. 4: Diagnoses

\begin{tabular}{||c|c|c||}
\hline Diagnosis & $\begin{array}{c}\text { Brno } \\
\text { (No. of pupils with } \\
\text { a given diagnosis) }\end{array}$ & $\begin{array}{c}\text { Litovel } \\
\text { (No. of pupils with } \\
\text { a given diagnosis) }\end{array}$ \\
\hline Hypermetropy & 6 & 16 \\
\hline Myopia & 5 & 3 \\
\hline Blindness & 6 & 3 \\
\hline $\begin{array}{c}\text { Disorders } \\
\text { of binocular vision }\end{array}$ & - & 8 \\
\hline Macular degeneration & - & 1 \\
\hline Glaucoma & 5 & - \\
\hline
\end{tabular}

Pupils investigated were requested to state the type of their visual impairment. From the acquired results follows: the questionnaire was answered by 22 pupils $(41.5 \%)$ with hypermetropy, 8 pupils (15.09\%) with myopia, 9 pupils $(16.98 \%)$ with blindness, 8 pupils $(15.09 \%)$ with disorders of binocular vision, 1 pupil (1.88\%) with macular degeneration and 5 pupils (9.43\%) with glaucoma. 
Tab. 5: Enrolment of pupils in the subjects of special-need pedagogical care

\begin{tabular}{||c|c|c||}
\hline $\begin{array}{c}\text { Subjects of special-need } \\
\text { pedagogical care }\end{array}$ & $\begin{array}{c}\text { Brno } \\
\text { (No. of pupils } \\
\text { in a given subject) }\end{array}$ & $\begin{array}{c}\text { Litovel } \\
\text { (No. of pupils } \\
\text { in a given subject) }\end{array}$ \\
\hline Visual stimulation & 4 & - \\
\hline $\begin{array}{c}\text { Spatial orientation } \\
\text { and Braille font }\end{array}$ & 6 & 2 \\
\hline $\begin{array}{c}\text { Remedy of specific } \\
\text { learning disabilities }\end{array}$ & 3 & 5 \\
\hline Speech therapy & 4 & 7 \\
\hline Not applicable & 5 & 17 \\
\hline
\end{tabular}

The table shows that many pupils attending a special school for the visually impaired take part in the subjects of special-need pedagogical care. In Brno, it is 17 out of 22 pupils ( $77.27 \%$ ), in Litovel it is 14 out of 31 pupils $(45.16 \%)$. It is thus obvious that these subjects are allocated to particular pupils based on their individual needs and, first of all, based on recommendations stated in their individual education plan.

Tab. 6a: Use of special tools in a primary school in Brno

\begin{tabular}{|c|c|c|c|c|c|c|}
\hline Tools & $\begin{array}{l}\text { Picht } \\
\text { type- } \\
\text { writer }\end{array}$ & $\begin{array}{l}\text { Hand } \\
\text { magnifying } \\
\text { glass }\end{array}$ & $\begin{array}{l}\text { Camera } \\
\text { magnifying } \\
\text { glass }\end{array}$ & $\begin{array}{l}\text { Adjust- } \\
\text { ments (note } \\
\text { pads, work } \\
\text { sheets) }\end{array}$ & $\begin{array}{l}\text { Tools } \\
\text { for arts }\end{array}$ & Others \\
\hline Pupil 1 & - & $\mathrm{x}$ & - & $\mathrm{x}$ & - & $\mathrm{x}$ \\
\hline Pupil 2 & - & - & - & - & - & - \\
\hline Pupil 3 & - & - & - & - & - & - \\
\hline Pupil 4 & - & - & - & - & - & - \\
\hline Pupil 5 & $\mathrm{x}$ & & $\mathrm{x}$ & $\mathrm{x}$ & $\mathrm{x}$ & $\mathrm{x}$ \\
\hline Pupil 6 & $\mathrm{x}$ & - & - & $\mathrm{x}$ & $\mathrm{x}$ & $\mathrm{x}$ \\
\hline Pupil 7 & - & $\mathrm{x}$ & $\mathrm{x}$ & $\mathrm{x}$ & - & - \\
\hline Pupil 8 & - & $\mathrm{x}$ & $\mathrm{x}$ & $\mathrm{x}$ & $\mathrm{x}$ & $\mathrm{x}$ \\
\hline Pupil 9 & - & $\mathrm{x}$ & $\mathrm{x}$ & $\mathrm{x}$ & - & - \\
\hline Pupil 10 & $\mathrm{x}$ & - & - & $\mathrm{x}$ & $\mathrm{x}$ & $\mathrm{x}$ \\
\hline
\end{tabular}




\begin{tabular}{|c|c|c|c|c|c|c|}
\hline Tools & $\begin{array}{l}\text { Picht } \\
\text { type- } \\
\text { writer }\end{array}$ & $\begin{array}{l}\text { Hand } \\
\text { magnifying } \\
\text { glass }\end{array}$ & $\begin{array}{l}\text { Camera } \\
\text { magnifying } \\
\text { glass }\end{array}$ & $\begin{array}{l}\text { Adjust- } \\
\text { ments (note } \\
\text { pads, work } \\
\text { sheets) }\end{array}$ & $\begin{array}{l}\text { Tools } \\
\text { for arts }\end{array}$ & Others \\
\hline Pupil 11 & $\mathrm{x}$ & - & - & $\mathrm{x}$ & $\mathrm{x}$ & $\mathrm{x}$ \\
\hline Pupil 12 & - & - & - & - & - & - \\
\hline Pupil 13 & - & - & $\mathrm{x}$ & $\mathrm{x}$ & - & - \\
\hline Pupil 14 & - & - & - & - & - & - \\
\hline Pupil 15 & - & $\mathrm{x}$ & $\mathrm{x}$ & $\mathrm{x}$ & - & $\mathrm{x}$ \\
\hline Pupil 16 & - & - & - & - & - & - \\
\hline Pupil 17 & - & - & - & $\mathrm{x}$ & - & - \\
\hline Pupil 18 & - & - & $\mathrm{x}$ & $\mathrm{x}$ & - & - \\
\hline Pupil 19 & - & - & - & - & - & - \\
\hline Pupil 20 & $\mathrm{x}$ & - & - & - & - & $\mathrm{x}$ \\
\hline Pupil 21 & - & - & & - & - & - \\
\hline Pupil 22 & - & - & - & - & - & - \\
\hline
\end{tabular}

Tab. 6b: Use of special tools in a primary school in Litovel

\begin{tabular}{|l|l|l|l|l|l|l||}
\hline \hline Tools & $\begin{array}{l}\text { Picht } \\
\text { typewriter }\end{array}$ & $\begin{array}{l}\text { Hand } \\
\text { magnifying } \\
\text { glass }\end{array}$ & $\begin{array}{l}\text { Camera } \\
\text { magnifying } \\
\text { glass }\end{array}$ & $\begin{array}{l}\text { Adjustments } \\
\text { (note pads, } \\
\text { work sheets) }\end{array}$ & $\begin{array}{l}\text { Tools } \\
\text { for arts }\end{array}$ & Others \\
\hline Pupil 1 & - & - & $\mathrm{x}$ & $\mathrm{x}$ & - & - \\
\hline Pupil 2 & - & - & $\mathrm{x}$ & $\mathrm{x}$ & - & - \\
\hline Pupil 3 & - & - & $\mathrm{x}$ & $\mathrm{x}$ & - & - \\
\hline Pupil 4 & - & - & $\mathrm{x}$ & $\mathrm{x}$ & - & $\mathrm{x}$ \\
\hline Pupil 5 & - & - & $\mathrm{x}$ & $\mathrm{x}$ & - & $\mathrm{x}$ \\
\hline Pupil 6 & - & - & - & - & - & - \\
\hline Pupil 7 & $\mathrm{x}$ & - & - & $\mathrm{x}$ & - & $\mathrm{x}$ \\
\hline Pupil 8 & - & - & - & - & - & - \\
\hline Pupil 9 & - & - & - & - & - & - \\
\hline Pupil 10 & - & - & - & $\mathrm{x}$ & - & - \\
\hline Pupil 11 & - & - & $\mathrm{x}$ & - & - & - \\
\hline
\end{tabular}




\begin{tabular}{|c|c|c|c|c|c|c|}
\hline Tools & \begin{tabular}{|l} 
Picht \\
typewriter
\end{tabular} & $\begin{array}{l}\text { Hand } \\
\text { magnifying } \\
\text { glass }\end{array}$ & $\begin{array}{l}\text { Camera } \\
\text { magnifying } \\
\text { glass }\end{array}$ & $\begin{array}{l}\text { Adjust- } \\
\text { ments (note } \\
\text { pads, work } \\
\text { sheets) }\end{array}$ & $\begin{array}{l}\text { Tools } \\
\text { for arts }\end{array}$ & Others \\
\hline Pupil 12 & - & - & - & - & - & - \\
\hline Pupil 13 & - & - & - & - & - & - \\
\hline Pupil 14 & - & - & - & - & - & - \\
\hline Pupil 15 & - & - & - & $\mathrm{x}$ & $\mathrm{x}$ & - \\
\hline Pupil 16 & - & - & - & $\mathrm{x}$ & $\mathrm{x}$ & - \\
\hline Pupil 17 & - & - & - & $\mathrm{x}$ & $\mathrm{x}$ & - \\
\hline Pupil 18 & - & - & - & $\mathrm{x}$ & $\mathrm{x}$ & - \\
\hline Pupil 19 & - & - & $\mathrm{x}$ & $\mathrm{x}$ & - & - \\
\hline Pupil 20 & - & - & $\mathrm{x}$ & $\mathrm{x}$ & - & - \\
\hline Pupil 21 & - & - & $\mathrm{x}$ & $\mathrm{x}$ & - & - \\
\hline Pupil 22 & $\mathrm{x}$ & - & $\mathrm{x}$ & $\mathrm{x}$ & $\mathrm{x}$ & - \\
\hline Pupil 23 & - & - & - & - & - & - \\
\hline Pupil 24 & - & - & - & - & - & - \\
\hline Pupil 25 & - & - & - & - & - & - \\
\hline Pupil 26 & & $\mathrm{x}$ & $\mathrm{x}$ & $\mathrm{x}$ & & $\mathrm{x}$ \\
\hline Pupil 27 & $\mathrm{x}$ & & & $\mathrm{x}$ & $\mathrm{x}$ & $\mathrm{x}$ \\
\hline Pupil 28 & - & - & $\mathrm{x}$ & $\mathrm{x}$ & - & - \\
\hline Pupil 29 & - & $\mathrm{x}$ & - & $\mathrm{x}$ & - & - \\
\hline Pupil 30 & - & - & - & - & - & - \\
\hline Pupil 31 & - & - & $\mathrm{x}$ & - & - & - \\
\hline
\end{tabular}

From tables $4 \mathrm{a}$ and $4 \mathrm{~b}$ follows that pupils with visual impairment have the chance to use special compensatory tools, which allow them to work in a lesson in a standard way, the essential ones being Picht braille typewriter or certain types of magnifying glasses. Text editing, especially its enlargement, the option to use free sheets of paper with adjusted and highlighted lines instead of bound exercise books, adjusted pictures, highlighting markers or texts in Braille font, etc., are an integral part of the teaching for these students. Another category special tools - includes e.g., special drawing set for the blind or a notebook specific for teaching visually impaired students at primary schools, more and more frequented. These notebooks are usually equipped with special software facilitating sound or enlargement of the entire setting. Some of the students state that they use calculators with voice output or Aria. 
Tab. 7: Other subsidiary measures applied in teaching

\begin{tabular}{||c|c|c|}
\hline $\begin{array}{c}\text { Subsidiary measures } \\
\text { in teaching }\end{array}$ & Brno & Litovel \\
\hline Inter-active teaching materials & 11 & 13 \\
\hline Audio-records & 5 & 13 \\
\hline Preference for oral testing & 12 & 19 \\
\hline
\end{tabular}

Subsidiary measures applied in the course of teaching by teachers themselves are undoubtedly highly creditable. The most important measure for pupils with visual impairment seems to be the chance to choose oral testing by the majority of teachers over other types of testing. The above results show that the advantages of such an option are availed by 12 out of 22 pupils in Brno and by 19 out of 31 pupils in Litovel. Nowadays, teachers tend to prefer rather written testing as this allows for testing a whole group of pupils in a relatively short period of time. However, this method of testing may not be suitable for pupils with visual impairment. In addition, the time stress combined with visual handicap can cause significant difficulties and thus influence the very result of the test. Further outputs show that interactive teaching materials are also applied in lessons, most frequently the commented and voice presentations, pre-prepared materials for working in pairs or groups as well as audio records and sound material presented through the voice activated notebook.

Our project attempts at bringing a new insight to the issue of education quality for students with visual impairment within the special-need teaching. It is assumed that after completion of the project, its findings will be applied in enhancing theoretical as well as practical preparation of future teachers for working with visually impaired pupils. Further, our ascertained experience can be obviously passed on to other schools, which might, in future, consider enrolling a pupil with this handicap to the education process. Our research thus allows individualizing the current status in the field of education of visually impaired pupils. The outputs of our research examination shall be summarized in a bulletin, which should serve both for institutions providing education to visually impaired students and for universities taking part in the training future special-need teachers focussing on people with visual impairment.

\section{CONCLUSION}

The issue of educating students with visual impairment is highly specific and focuses on a wide range of related aspects. In case we target the education quality, then it is necessary to consider the various specifics influencing lesson quality, both in the positive and negative ways. The fact to be taken into account 
are as follows: the type of school a pupil attends, whether or not he/she is under the auspices of an education consultancy body, the type of compensatory tools he/she uses in teaching with respect to the handicap, to what extent and how the particular handicap affects his/her work in a lesson, whether or not a teacher assistant is required in a lesson, etc. Each of these factors can influence the quality of education provided, whereas prime quality education is essential for due implementation of the education process, marginally for the teachers but primarily for the students themselves.

\section{List of literature and professional sources}

Finková, D., Ludíková, L., Růžičková, V. (2007) Speciální pedagogika osob se zrakovým postižením. Olomouc: UP.

Chodounská, H. Zpráva o novorozenci 2010. 11[1] pdf. [on line] Praha: Ústav zdravotnických informací a statistiky ČR. Dostupné z: http://www.uzis.cz/ rychle-informace/zprava-novorozenci-2010.

Jesenský, J. (1995) Uvedeni do rehabilitace zdravotně postižených. Praha: Karolinum. Vágnerová, M. (1995) Oftalmopsychologie dětského věku. Praha: Karolinum.

Votava, J. (2005) Ucelená rehabilitace osob se zdravotním postižením. Praha: Karolinum.

Vyhláška č. 73/2005 Sb., o vzdèláváni dètí, pupils a studentů se speciálními vzdělávacími potřebami a dètí, pupils a studentů mimořádnè nadaných. [on line] 7. 6. 2011 [cit. 14. 4. 2012] Dostupné z: http://www.vuppraha.cz/ wp-content/uploads/2010/02/Nadani_prehled.pdf.

Zákon č. 561/2004 Sb. o předškolním, základním, středním, vy̌̌ším odborném a jiném vzdèlávání. [on line] 3. 1. 2012 [cit. 14. 4. 2012] Dostupné z: http:// www. msmt.cz/dokumenty/novy-skolsky-zakon

\section{Contact}

Mgr. Dita Finková, Ph.D.

Institute of Special Education Studies

Faculty of Education

Palacký University Olomouc

Žižkovo nám. 5

77140 Olomouc.

E-mail: ditafinkova@seznam.cz

Phone: +420 585635339 